\title{
Identification of Zingiberaceae as medicinal plants in Gunung Cut Village, Aceh Barat Daya, Indonesia
}

\author{
Meutia Zahara*, Mauizah Hasanah, Rahma Zalianda \\ Department of Biology, Muhammadiyah Aceh University, Banda Aceh, Indonesia \\ *Corresponding author: teeya_razali@yahoo.co.id
}

\section{ARTICLE HISTORY}

Received: 18 July 2018

Revised: 28 July 2018

Accepted: 22 September 2018

\section{KEYWORDS}

Zingiberaceae

Gunung Cut

Medicinal plants

\begin{abstract}
Zingiberaceae is well known as gingers family with abundant numbers of spices widely used in Southeast Asia, because of their unique flavors, ornamental and also the medicinal values. The extracts of Zingiberaceae rhizome contain many essentials oils, including terpenes, alcohols, ketones, flavonoids and phytoestrogens that use as medicine. Zingiberaceae grow vigorously in a wide range of habitats ranging from riverine to the limestone area, from lowland to the upper mountain regions. They often grow in shady area but some of the native species are able to tolerate to the sun exposure. The cultivation of this family was developed widely. Gunung Cut Village is one the villages in Aceh Barat Daya district which cultivated four species of this family: Zingiber officinale, Curcuma domestica, Alpina galanga and Kaempferia galanga. They mainly use for medicinal purposes as it can cure many diseases traditionally.
\end{abstract}

This is an open access article under the CC-BY-SA license.

\section{INTRODUCTION}

Zingiberaceae is well known as gingers family with abundant numbers of spices widely used in Southeast Asia because of their unique flavors, ornamental and also the medicinal values (Aggarwal and Shishodia, 2006). The extracts of Zingiberaceae rhizome contain many essentials oils, including terpenes, alcohols, ketones, flavonoids and phytoestrogens that use as medicine. Zingiberaceae grow vigorously in a wide range of habitats ranging from riverine to the limestone area, from lowland to the upper mountain regions, they often grow in shady area but some of the native species are able to tolerate to the sun exposure (Larsen, 1999). Jatoi et al. (2007) mentioned that Zingiberaceae as the largest families in the plant kingdom, are distributed mainly in the tropical Asia. They comprise not only a prominent fraction of the undergrowth of tropical rain forest and monsoon forest, but also found in the secondary forest (Chen, 1989). As used gingers, this family consists of some genera such as; Alpina, Amomum, Curcuma, and Zingiber, followed by Boesenbergia, Kaempferia, Elettaria, Elettariopsis, Etlingera, and Hedychium are the most important. Most of the species are rhizomatous where the propagation often occurs through rhizomes (Jatoi et al., 2007).

Members of Zingiberaceae are usually aromatic in all part of plant, has functions as natural sources of spices, herbal medicine, natural dyes, perfumes and multipurpose of aesthetic compounds (Sirirugsa, 1999 in
Jatoi et al, 2007). Zingiberaceae vary in height and size, from gigantic erect leafy shoots, which in some species achieve more height more than $8 \mathrm{~m}$ (e.g., Etlin-gera elatior), to plant as small as $10 \mathrm{~cm}$ or at nearly ground level such as Kaempferia galanga (Larsen et al, 1999). Zingiberaceace grown almost in all gardens in Gunung Cut Village. This village is the capital city of Tangan-tangan district in Aceh Barat Daya, Aceh, Indonesia with total area about 1.046 Ha. This area belongs to the tropical rain forest, where the society has a main job in growing Zingiberaceaeas medicinal and economical values. They use Zingiberaceae for many diseases such as; ear inflammation, cataract, kidney, infertility and others.

\section{MATERIALS AND METHODS}

\subsection{Study area}

The research was conducted from July to August 2018. All areas in Gunung Cut Village were selected for data collections.

\subsection{Data collection}

Data were collected through observation, documentation and personal interviews with the society (informant) using Snowball sampling (Chain sampling), where the information obtained from the main sources then could developed for further information's. The informant determined based on the information from the leader in 
Gunung Cut Village such as; tribal leader, the head of the village, and trusted sources who know deeply related to research activities carried out.

\section{RESULTS AND DISCUSSION}

The results obtained in this study, from the informants, herbal medicine practitioner and the society in Gunung Cut Village mainly grow four species of Zingiberaceae (Table 1.). Those species found could recover some diseases. Nature has been a source of medicinal agents for thousands of years and a lot of number of modern drugs has been isolated from natural sources that play a vital role in treatment of diseases (Cragg and Newman, 2001). Traditional medicinal plants usage are often cheaper, locally available and easily consumable, raw or as simple medicinal preparations. These simple medicinal preparations often bring out beneficial responses due to their active chemical constituents (Park and Pezutto, 2002). Natural chemical content in medicinal plants are generally known as "Chemical Goldmines" which are acceptable to human and animal system. Those important chemical cannot be synthesized in the laboratories. A lot of secondary metabolites in plant are commercially important and find use for pharmaceutical compounds. Human beings have been dependent on plants for their health care needs since the beginning of civilization. More than 80.000 plant species on earth are medicinal use (Dhanik et al., 2017).

Table 1. Species from Zingiberaceae grown in Gunung Cut Village, Aceh Barat Indonesia

\begin{tabular}{cccc}
\hline No. & Local Name & Scientific Name & Main traditional medicine usage \\
\hline 1. & Jahe (Ginger) & Zingiber officinale Rosc. & Anti-inflammatory, relieve pain, anti-bacteria. \\
2. & Kunyit (Turmeric) & Curcuma domestica Val. & Gastritis, dyspepsia, joint pain, reduce pain during menstruation \\
3. & Lengkuas (galangal) & Alpinia galangal L. & Relieve chest pain, sore throat, antifungal \\
4. & Kencur & Kaempferia galanga $\mathrm{L}$. & Fever, swollen, rheumatism \\
\hline
\end{tabular}

\subsection{Zingiber officinale}

Zingiber officinale (Figure 1) is well known as ginger, one of the most important members from Zingiberaceae family. It values for medicinal, nutritional, and ethnobotanical and extensively use worldwide as a spice, flavoring agent and herbal remedy (Grzanna et al., 2005; Dhanik et al., 2017). Phytochemical studies of gingers show that the rhizome contains a wide variety of biologically active compounds which impart medicinal property. Ginger is reported to possess essential oils, phenolic compound, flavonoids, carbohydrates, proteins, alkaloids, glycosides, saponins, steroid, terpenoids and tannin as the major phytochemical groups (Dhanik et al., 2017). Ginger in Gunung Cut Village mainly used as herbal medicine to cure variety diseases; nausea, vomiting, asthma, cough, palpitation, inflammation, dyspepsia, loss of appetite, constipation, indigestion and pain.

\section{Scientific classification:}

$\begin{array}{ll}\text { Kingdom } & \text { : Plantae } \\ \text { Division } & \text { : Magnoliophyta } \\ \text { Class } & \text { : Liliopsida } \\ \text { Order } & \text { : Zingiberales } \\ \text { Family } & \text { : Zingiberaceae } \\ \text { Genus } & \text { : Zingiber } \\ \text { Species } & : \text { Zingiber officinale Rosc. }\end{array}$

(Gupta and Sharma, 2014).
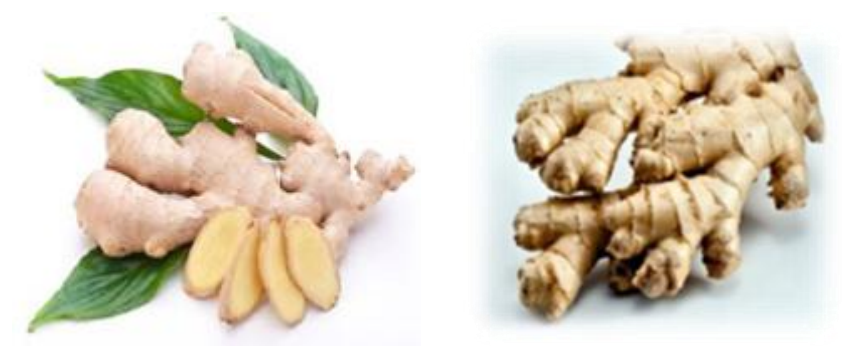

Figure 1. Rhizome of Zinger officinale (Gupta and Sharma, 2014).

According to Food and Agricultural Organization of United Nations: Economic and Social department: The statistical division (2013), Indonesia is one of top ten gingers producing country in the world (Table 2).

Table 2. Top ten gingers producing country

\begin{tabular}{ccc}
\hline No & Country & Producing (Tonnes) \\
\hline 1. & India & 683.000 \\
2. & China & 425.000 \\
3. & Nepal & 235.033 \\
4. & Indonesia & 232.669 \\
5. & Nigeria & 16.000 \\
6. & Thailand & 14.000 \\
7. & Bangladesh & 69.000 \\
8. & Japan & 57.835 \\
9. & Cameroon & 46.350 \\
10. & Philippines & 28.216 \\
\hline
\end{tabular}

\subsection{Curcuma domestica Vall}

Turmeric (Figure 2) is a spice that has received much interest from both the medical and scientific worlds as well as from the culinary world (Priyadarsini, 2014). Curcumin has received worldwide attention for its multiple health benefits, including in Gunung Cut Village, they cultivated curcumin mainly for its health benefits especially through its anti-oxidant and anti-inflamatory mechanisms. According to Hewlings and Kalman (2017), these benefits are best achieved when curcumin is 
combined with agents such as piperine, which increase its bioavailability significantly. It suggested that curcumin can help in the management of oxidative and inflammatory conditions, metabolic syndrome, arthritis, anxiety, and hyperlipidemia. It may also help in the management of exercise-induced inflammation and muscle soreness.

Curcumin is an important constituent of turmeric. A yellow-pigmented fraction isolated from the rhizomes of Curcuma contains curcuminoids belonging to dicinnamoyl methane group. Curcuminoids are presented to the extent of $3-5 \%$. It is an important active ingredient responsible for the biological activity of Curcuma (Pandey and Katiyar, 2010).

$\begin{array}{ll}\text { Scientific classification } \\ \text { Kingdom } & \text { : Plantae } \\ \text { Division } & \text { : Magnoliophyta } \\ \text { Class } & \text { : Liliopsida } \\ \text { Order } & : \text { Zingiberales } \\ \text { Family } & : \text { Zingiberaceae } \\ \text { Genus } & : \text { Curcuma } \\ \text { Species } & : \text { Curcuma domestica Vall }\end{array}$

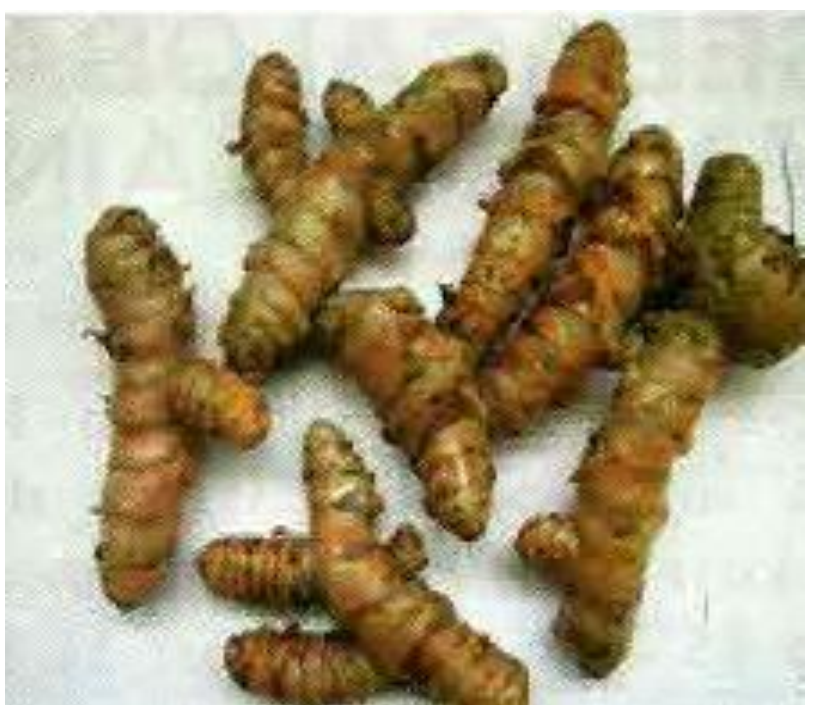

Figure 2. Tumeric rhizome (Hartati, 2013)

\subsection{Alpinia galanga (galangal)}

The people in Gunung Cut Village intensively cultivate galangal (Figure 3) in their garden. The mixture of galangal with warm water could recover chest pain and sore throat. According to the explanation of Verma et al. (2011), different parts of this plant are traditionally used for the treatment of ailments including anti-fungal, anti-tumor, anti-helminthic, anti-diuretic, anti-ulcerative, heart disease, rheumatic pains, chest pain, dyspepsia fever, diabetes, burning of liver and kidney disease.

$\begin{array}{ll}\text { Order } & : \text { Zingiberales } \\ \text { Family } & : \text { Zingiberaceae } \\ \text { Genus } & : \text { Alpinia } \\ \text { Species } & : \text { Alpinia galanga }\end{array}$

Galangal is a native of Indonesia although its exact origin is not known, but it naturalized spread to many parts of South and South East Asia. The oldest reports about its use and existence are from southern China and Java. The sub-Himalayan zone is also believed to be a natural home of galangal. It is mostly cultivated in home gardens and organized plantations do not exist. The Netherlands imports yearly over 100 tons of fresh rhizomes and about 30 tons of dried rhizomes. The main suppliers are Thailand, Indonesia and India (Scheffer and Jansen, 1999). Many investigations have been done for chemical content of galangal rhizome. The analyzed of a rhizome sample from Indonesia reported 1,8-cineole (47.3\%), $\alpha$-pinene $(11.5 \%), \quad \beta$-pinene $(7.1 \%), \quad \alpha$-thujene $(6.2 \%)$, terpinen-4-ol (6.0\%), $\alpha$-terpineol, limonene ( $4.3 \%$ each) and many other compounds in lower concentrations (Ravindran and Divakaran, 2012).

\subsection{Kaempferia galangal L.}

Another important herb from Zingiberaceae that cultivated in Gunung Cut Village as herbal medicine is Kaempferia galanga L. Well known as kencur in Bahasa Indonesia. The society in Gunung Cut uses this herbs to cure fever, swollen and rheumatics also for culinary. The medicinal value of each parts of Kaempferia galangal L. have been studied for years. The rhizome, root stocks and leaves are used in different way for different medicinal purposes (figure 3). The leaves traditionally can be used for anti-inflammation, cure the sore throat, mood stabilizer, and increase the stamina. While the rhizome consumes for curing the diarrhea, anti-cancer, and stomachache.

$\begin{array}{ll}\text { Scientific classification } \\ \text { Kingdom } & \text { : Plantae } \\ \text { Division } & \text { : Magnoliophyta } \\ \text { Class } & \text { : Liliopsida } \\ \text { Order } & \text { : Zingiberales } \\ \text { Family } & \text { : Zingiberaceae } \\ \text { Genus } & \text { : Kaempferia } \\ \text { Species } & \text { : Kaempferia galangal L. }\end{array}$

According to the research had been done by Kanjanapothi et al (2004), Kaempferia galangal L. has a lot of pharmacological activity, can be seen in the Table. 3 .

$\begin{array}{ll}\text { Scientific classification } \\ \text { Kingdom } & \text { : Plantae } \\ \text { Division } & \text { : Magnoliophyta } \\ \text { Class } & \text { : Liliopsida }\end{array}$


Table 3. Pharmacological activities of Kaempferia galanga L. extracts with possible mechanism of action

\begin{tabular}{|c|c|c|}
\hline Pharmacological activities & Responsible constituents & Possible mechanism of action \\
\hline Analgesic and anti- inflammatory & & $\begin{array}{l}\text { Central mechanism involving opioid and peripheral } \\
\text { mechanism involving cyclooxygenase pathway } \\
\text { (Ridtitid et al., 2008; Sulaiman et al., 2008) }\end{array}$ \\
\hline Nematicidal activity & $\begin{array}{l}\text { Ethyl-trans-cinnamate, } \\
\text { ethyl-p-methoxycinnamate } \\
\text { (Hong et al., 2011) }\end{array}$ & $\begin{array}{l}\text { Mode of delivery of constituents is partly through steam } \\
\text { phase. Mechanism is still unclear } \\
\text { (Hong et al, 2011). }\end{array}$ \\
\hline $\begin{array}{l}\text { Mosquito repellent and larvicidal } \\
\text { activity }\end{array}$ & $\begin{array}{l}\text { ethyl-p-methoxycinnamate, ethyl-cinnamate, } \\
\text { 3-carene, 2-propionic acid (Kim et al., 2008; } \\
\text { Sutthanont et al., 2010) }\end{array}$ & $\begin{array}{l}\text { Destruction of ionic regulation in the anal gills } \\
\text { (Insun et al., 2010). }\end{array}$ \\
\hline Vasorelaxant activity & ethyl-cinnamate (Othman et al., 2006) & $\begin{array}{l}\text { Inhibition of calcium influx into vascular cells, release of } \\
\text { nitric oxide and prostaglandins from endothelial cells } \\
\text { (Othman et al., 2002). }\end{array}$ \\
\hline Antineoplastic activity & $\begin{array}{l}\text { ethyl-p-methoxycinnamate } \\
\text { (Liu et al., 2010) }\end{array}$ & $\begin{array}{l}\text { Translocation of phosphatidylserine of Hep G2 cells to cell } \\
\text { surface, resulting in an increase in sub-G cell population } \\
\text { (Liu et al., 2010). }\end{array}$ \\
\hline Anti-oxidant activity & $\begin{array}{l}\text { Total phenolic content and flavonoids } \\
\text { including luteolin and apigenin } \\
\text { (Mustafa et al., 2010) }\end{array}$ & \\
\hline Anti-microbial activity & $\begin{array}{l}\text { ethyl-p-methoxycinnamate } \\
\text { (Kanjanapothi et al., 2004) }\end{array}$ & \\
\hline
\end{tabular}

From a review about this herbs mentioned that Kaempferia galangal L. is a major plant with many valuable medicinal properties. Although the rhizome is the main source of active principles, leaves are also being used in traditional medicine to treat swelling, headache, rheumatism etc. Extract of Kaempferia galangal L. have antioxidant, antimicrobial, analgesic, mosquito repellent sedative and wound healing activities (Nag and Mandal, 2015)

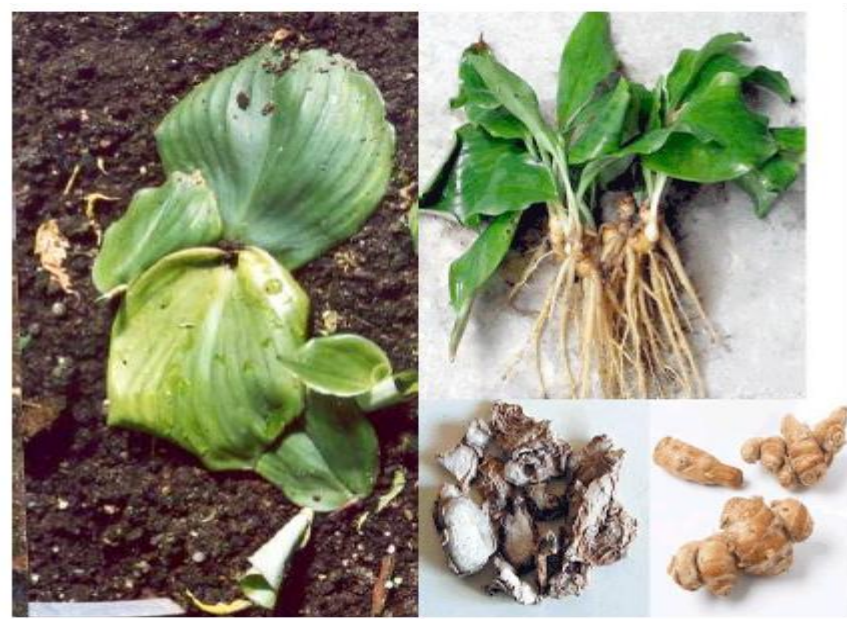

Figure 3. Different part of Kaempferia galangal L. (Nag and Mandal, 2015)

\section{CONCLUSION}

Gunung Cut is a village located in Aceh Barat Daya district, Aceh province, Indonesia. Zingiberaceae intensively cultivated in home garden in this village as medicinal plants, herbs, spice and economic purpose. There are four species of Zingiberaceae; Zingiberofficinale, Curcuma domestica Vall., Alpina galangal L., and Kaempferia galangal L.

\section{REFERENCES}

Aggarwal, B. B., S. Shishodia. 2006. Molecular targets of dietary agents for prevention and therapy of cancer. Biochemical Pharmacology 71 (2006) 1397-1421.

Chen, Y. Z. 1989. Evolutionary pattern in cytology and pollen structure of Asian Zingiberaceae. In: Holm-Nielsen LB, Nielsen IC, Balslev H (Eds) Tropical Forest: Botanical Dynamics Speciation and Diversity, Academic Press, Harcourt Brave Jovanovich, Publisher. Tokyo, pp 185-191.

Cragg, G. M., D. J. Newman. 2001. Medicinal for the Millennia.Annals of the New York Academy of Sciences.

Dhanik, J., A. Arya, V. Nand. 2017.A Review on Zingiber officinale. Journal of Pharmacognosy and Phytochemistry, 6(3): 174-184

Food and agricultural Organizations or United Nations: Economic and Social Department. Statistical division. 2013.

Gupta, S. K., A. Sharma. 2014. Medicinal Properties of Zingiber officinale Roscoe. A Review. IOSR - Journal of Pharmacy and Biological Sciences (IOSR-JPBS)

Hartati, S. Y. 2013. Khasiat kunyit sebagai obat dan manfaat lainnya. Warta penelitian dan Pengembangan Tanaman Industri, Vol. 19, No.

Hong, T. K., S. I. Kim, J. W. Heo, J. K. Lee, D. R. Choi, Y. J. Ahn. 2011. Toxicity of Kaempferia galanga rhizome constituents to Meloidogyne incognita juveniles and eggs. Nematology, 13: 235-244.

Hewlings, S. J and Kalman D. S. 2017. Curcumin: A review of its effects on human health. Foods 6, 92

Insun D., W. Choochote, A. Jitpakdi, U. Chaithong, P. Tippawangkosol, B. Pitasawat. 1999. Possible site of action of Kaempferia galanga in killing Culex quinquefasciatus larvae. Southeast Asian J. Trop. Med. Public Health, 30: 195-199.

Jatoi, S. A., A. Kikuchi, N. Kazuo, Watanabe. 2007. Genetic Diversity, Cytology, and Systematic and Phylogenic studies in Zingiberaceae. Genes, Genomes and Genomics. Global Science Books.

Kanjanapothi, D., A. Panthong, N. Lertprasertsuke, T. Taesotikul, C. Rujjanawate, D. Kaewpinit, R. Sudthayakorn, W. Choocote, U. Chaitong, A. Jitpakdi, B. Pitasawat. 2004. Toxicity of crude rhizome extract of Kaempferia galanga L. Journal of Ethnopharmacology 90: 359-365.

Kim N.J., S. G. Byun, J. E. Cho, K. Chung, Y. J. Ahn. 2008. Larvicidal activity of Kaempferia galanga rhizome phenylpropanoids towards three mosquito species. Pest Manage. Sci., 64: 857-862.

Larsen, T.M., S. M. Boehlein, N. G. Richard, J. B. Thoden, H. M. Holden, I. 
Rayment.1999. Three-dimensional structure of Escherichia coli asparagine synthetase B: a short journey from substrate to product. Biochemistry 38(49): 16146-57.

Liu B, F. Liu, C. Chen, H. Gao. 2010. Supercritical carbon dioxide extraction of ethyl p-methoxycinnamate from Kaempferia galanga L. rhizome and its apoptotic induction in human HepG2 cells. Nat. Prod. Res., 24: 1927-1932.

Mustafa R.A., H. A. Abdul, S. Mohamed, F. A. Bakar. 2010. Total phenolic compounds, flavonoids, and radical scavenging activity of 21 selected tropical plants. J. Food Sci., 75: C28-C35.

Nag, S., S. Mandal. 2015. Importance of Ekangi (Kaempferia galangal L.) as Meidicinal plants- A Review

Othman R., H. Ibrahim, M. A. Mohd, K. Awang, A. U. H. Gilani, M. R. Mustafa. 2002. Vasorelaxant effects of ethyl cinnamate isolated from Kaempferia galanga on smooth muscles of the rat aorta. Planta. Med., 68: 655-657.

Pandey, A., S. K. Katiyar. 2010.Determination and Comparison of the Curcuminoid Pigments in Turmeric Genotypes (Curcuma domestica vall) by high-perfomance liquid chromatography. International Journal of pharmacy and pharma chemical sciences. Vol. 2.Issue 4.

Park, E. J., J. M. Pezutto. 2002.Botanicals in cancer chemoprevention, Cancer and Metastasis Reviews.

Priyadarsini, K. I. 2014.The chemistry of curcumin: From extraction to therapeutic agent. Molecules 19. 20019-20112.

Ravindran, P. N., M. Divakaran. 2012. Handbook of herbs and spice.Second edition.Wood Publishing series in Food Science, Technology and nutrition.Pp. 303-318

Ridtitid W., C. Sae-Wong, W. Reanmongkol, M. Wongnawa. 2008. Antinociceptive activity of the methanolic extract of Kaempferia galanga Linn. in experimental animals. J. Ethnopharmacol., 118: 225- 230.

Scheffer, J. J. C., P. C. M. Jansen. 1999.Alpina galanga (L.) wild. Pp. 65-68. In C. C. de Guzman and Simonsma, J. S. (eds), Plant Resources of South-east Asia No.13. Spice. The backhuys publisher, Leiden, Netherlands.

Sulaiman M.R., Z. A. Zakaria, I. A. Daud, Ng FN, Ng YC., M. T. Hidayat. 2008. Antinociceptive and anti-inflammatory activities of the aqueous extract of Kaempferia galanga leaves in animal models. J. Nat. Med., 62: 221-227

Sutthanont N., W. Choochote, B. Tuetun, A. Junkum, A. Jitpakdi, U. Chaithon, D. Riyong, B. Pitasawat. 2010. Chemical composition and larvicidal activity of edible plant- derived essential oils against the pyrethroid-susceptible and -resistant strains of Aedes aegypti (Diptera: Culicidae). J. Vector Ecol, 35: 106-115.

Verma, R. K., G. Mishra, P. Singh, K.K. Jha, R. L. Khosa. 2011. Alpina galangal-An important Medicinal Plant: A Review. Pelagi Research Laboratory. 